\title{
PERSONAL RESPONSIBILITY FOR INTENTIONAL CONDUCT: PROTECTING THE INTERESTS OF INNOCENT CO-INSUREDS UNDER INSURANCE CONTRACTS
}

\author{
ELIZABETH ADJIN-TETTEY*
}

An insured who wilfully damages insured property cannot seek indemnification under an insurance policy because the loss was not a fortuitous one and likely falls within an exclusion clause in the policy. This has historically been referred to as the criminal forfeiture principle, which holds that for public policy reasons a wrongdoer should not be able to benefit from his or her own wrongdoing. The question in situations like this is whether an innocent co-insured should also be barred from recovery for such loss. This article focuses on developments in the law relating to recovery by an innocent co-insured - namely amendments to the British Columbia Insurance Act. The author explores the history of the criminal forfeiture principle and also examines the modern contractual approach to interpreting insurance contracts. This article argues that the modern approach emphasizes property and contract law principles at the expense of protecting the reasonable expectations of an innocent co-insured. The author then examines a key provision in the British Columbia Insurance Act that intends to provide statutory protection for an innocent co-insured. Despite some disadvantages, the author argues that the benefits of the statutory protection outweigh any potential weaknesses.
Un assuré qui intentionnellement cause un préjudice à des biens assurés ne peut pas obtenir de dédommagement en vertu de la police d'assurance parce que la perte n'était pas accidentelle et correspond probablement à la clause d'exception de la police. Ce principe s'appelle normalement principe de la déchéance criminelle, c'est-à-dire que pour des raisons de politiques publiques un auteur d'un méfait ne peut pas profiter du méfait commis. Le cas échéant, il faut se demander si un coassuré innocent doit également être privé de l'indemnisation de la perte en question. Cet article porte sur les développements du droit en ce qui concerne le dédommagement d'un coassuré innocent, notamment les amendements à la Loi sur les assurances de la Colombie-Britannique. L'auteur explore l'historique du principe de la déchéance criminelle et examine l'approche contractuelle moderne à l'interprétation des contrats d'assurance. L'auteur fait valoir que l'approche moderne se fonde sur les principes du droit des biens et du droit du contrat au lieu de protéger les attentes raisonnables d'un coassuré innocent. L'auteur examine ensuite la disposition clé de la Loi sur les assurances de la Colombie-Britannique qui a pour but de fournir une protection législative à un coassuré innocent. Malgré certains inconvénients, l'auteur fait valoir que les avantages de cette protection législative l'emportent sur les faiblesses potentielles.

\section{TABLE OF CONTENTS}

I. INTRODUCTION . . . . . . . . . . . . . . . . . . . . . . . . . . . . . . . . . . 616

II. MODERNIZING INSURANCE LEGISLATION . . . . . . . . . . . . . . . . 617

III. Why IS SUCH A PROVISION NECESSARY? . . . . . . . . . . . . . . . 619

IV. CRIMINAL ForfEITURE PRINCIPLE . . . . . . . . . . . . . . . . . . . . 622

V. CLAIMS BY INNOCENT CO-INSUREDS: THE

Contractual APPROACH (MODERN APPROACH) . . . . . . . . . 623

VI. CONFLATING PROPERTY AND CONTRACT PRINCIPLES

AND UndERMINING PERSONAL RESPONSIBILITY . . . . . . . . . . . 625

VII. StAtutory PRotection of InNOCEnT Co-INSUREDS . . . . . . . . . 628

VIII. CONCLUSION ......................... 629

Professor, Faculty of Law, University of Victoria, eadjinte@uvic.ca. An abbreviated version of this article was published as Elizabeth Adjin-Tettey, "Protecting the Interests of the Innocent Insured," The Lawyers Weekly 31:33 (13 January 2012) 12. Thanks to Natalie Smith and Trevor Morley for their research and editorial assistance. 


\section{INTRODUCTION}

An insured who wilfully damages insured property cannot seek indemnification under the insurance contract because the damage or loss in these circumstances is not fortuitous and falls within the exclusion clause regarding loss intentionally caused by an insured. However, whether the insurer should be liable to indemnify a co-insured or unnamed insured where the loss is caused by the intentional conduct of another person insured under the same policy is a vexing question that demonstrates tensions between competing public policy considerations. Public policy rationales for the exclusion of recovery for such losses include preventing wrongdoers from benefitting from their own wrongdoing, deterring criminal activity, and preventing moral hazards. However, where an innocent co-insured has also suffered loss or damage to their insured interests, the question remains whether they should also be barred from recovery pursuant to the exclusion clause, as they were not implicated in the wrongdoing. How would an average insured not versed in the niceties of insurance law view the insurer's indemnification obligations to them under an insurance contract in such circumstances?

On one hand, indemnification for intentionally caused losses undermines two important rationales of insurance: providing coverage for fortuitous losses and the need to minimize moral hazards. On the other hand, non-indemnification for losses suffered by an innocent coinsured or unnamed insured unfairly punishes them for the wrongdoing of another, ignores the principle of personal responsibility for one's wrongdoing and undermines the consumer protection objective of insurance law. This position also entails a sense of making the innocent co-insured and unnamed insured vicariously liable for the wrongs of others. However, such persons would normally not be liable for the wrongdoer's conduct absent the requisite relationship that underpins vicarious liability, such as employer-employee and principal-agent, and personal wrongdoing on their part. More importantly, excluding claims of innocent co-insureds unconnected with intentionally caused loss seems to stem from the overlap between principles in different areas of law, specifically contract law and property law, as well as the tension between the concepts of relational interdependency and individual autonomy and responsibility that are central to legal liberalism.

The problem of innocent co-insureds often arises in the context of homeowners' policies where loss is caused by the deliberate conduct of one of those insured under the policy. Typically, joint owners are insured under the same policy and are collectively referred to as insured. As well, homeowner policies adopt a broad definition of "insured" to include other persons who may reside at the home, such as cohabitants, children, and relatives who are likely to suffer damage or loss if a risk materializes. These composite policies that protect multiple individuals are preferred as a matter of efficiency because they prevent the need for numerous individual policies and/or endorsements and avoid insureds having to deal with multiple insurers in the event of loss, subrogation, or contribution. Notwithstanding that the legal liberal order perceives individuals as autonomous legal subjects and assumes their detachment from one another, the reality is that people are connected and interdependent on each other with mutual vulnerabilities (though to varying degrees), and these composite policies reflect the relational element of human existence. The relationship among persons within a familial context tends to be characterized by intimacy, care and compassion, and a concern for each other's well-being. The named insured is often a person deemed to be in a 
special relationship with an unnamed insured or to have voluntarily assumed responsibility for the unnamed insured's well-being such that the law would readily impose a duty of care on the insured for the benefit of such persons. The named insured would likely consider having insurance protection for these persons if they were not covered under the contract in question. But this in no way suggests disregarding the autonomy and individuality of each person. In fact, there is no vicarious liability for another's conduct based on ties of kinship and assumption of responsibility; rather, liability is predicated on personal wrongdoing, including negligent supervision, that causes or contributes to the loss in question.

The broad definition of insured, although intended to reflect the reality of human relationships and to create economic efficiency, when coupled with the intentional or criminal conduct exclusion for loss or damage by an insured, has ended up being a source of unfairness for innocent co-insureds where damage or loss is caused by a person included in the definition of insured under the policy. This is particularly detrimental for women and children victims of domestic violence where the abusive partner or parent wilfully damages the subject property, usually the family home.

This article focuses on developments in the law relating to recovery by innocent insureds. British Columbia and Alberta have adopted provisions that allow an innocent co-insured to recover their proportionate interest in the insured property notwithstanding that loss or damage was caused by the deliberate conduct of another person insured under the same contract. This article explores the origins and rationale for the statutory changes and the public policy rationale for the change. Although there is a possibility of the perpetrator benefitting from the recovery by an innocent co-insured, the benefits are primarily for the innocent co-insured and are limited to his or her proportionate interest in the insured property.

\section{Modernizing INSURANCE LEGISLATION}

The Supreme Court of Canada has expressed frustration that the current structure of insurance legislation does not adequately reflect modern insurance practice. In KP Pacific Holdings Ltd. v. Guardian Insurance Co. of Canada, ${ }^{1}$ a case involving a missed limitation period for filing an insurance claim under a multi-peril policy, the Court stated that there was confusion regarding the applicable limitation periods for all risk policies because the risk and object-based classification of insurance contracts in the legislation did not reflect the structure of modern multi-risk or comprehensive insurance policies. The Court called on the British Columbia legislature (and by implication other Canadian provinces and territories) to revise their insurance legislation in order to bring them in line with current practices. ${ }^{2}$ This led to a review of the insurance legislation in British Columbia that culminated in the passage a new Insurance Act. ${ }^{3}$ In responding to this call for change, the legislature went beyond addressing the issues of classification of insurance contracts and also addressed other problematic areas in insurance law and practice. A principal objective of the amendment is

SBC 2012, c 37 [BC Insurance Act]. A similar process was initiated in Alberta which has also resulted in similar amendments to the Alberta Insurance Act, RSA 2000, c I-3 [Alberta Insurance Act], which came into force 1 July 2012 (Alberta OIC 325/2011, (2011) A Gaz I 580). 
to promote consumer protection, ${ }^{4}$ which is consistent with an important rationale for insurance regulation. ${ }^{5}$ One of the issues addressed in the new legislation is the situation of the innocent insured where loss to the subject property is caused by the intentional or criminal conduct of a co-insured. The issue often arises in the domestic context where a couple have joint ownership in the family home with their interests insured in a single insurance policy and one party intentionally damages or causes loss to the property. ${ }^{6}$

\section{Section 35 of the BC Insurance Act, states:}

(1) Despite section 5, if a contract contains a term or condition excluding coverage for loss or damage to property caused by a criminal or intentional act or omission of an insured or any other person, the exclusion applies only to the claim of a person

(a) whose act or omission caused the loss or damage,

(b) who abetted or colluded in the act or omission,

(c) who

(i) consented to the act or omission, and

(ii) knew or ought to have known that the act or omission would cause the loss or damage, or

(d) who is in a class prescribed by regulation.

(2) Nothing in subsection (1) allows a person whose property is insured under the contract to recover more than their proportionate interest in the lost or damaged property.

(3) A person whose coverage under a contract would be excluded but for subsection (1) must comply with any requirements prescribed by regulation. ${ }^{7}$

The provision is applicable in relation to claims of innocent insureds under insurance contracts already in existence on the date the provision came into force (1 July 2012). However, the provision is only applicable in relation to loss or damage occurring after the provision came into effect. ${ }^{8}$

The need to protect innocent insureds as part of the consumer-friendly regime was emphasized in discussions leading to the adoption of the BC Insurance Act. For example, it

$4 \quad$ British Columbia, Official Report of Debates of the Legislative Assembly (Hansard), 39th Parl, 1st Sess, Vol 2, No 3 (15 September 2009) at 371 (Hon C Hansen).

5 See Craig Brown, Introduction to Canadian Insurance Law, 2d ed (Markham: LexisNexis Butterworths, 2006) at 5.

6 Damage or loss may also be caused by a member of the household, such as a child or relative under the age of 21, and who is considered to have an insurable or beneficial interest in the property, as was the case in Scott v Wawanesa Mutual Insurance Co, [1989] 1 SCR 1445 [Scott].

7 BC Insurance Act, supra note 3, s 35. See also Alberta Insurance Act, supra note 3, s 541. It is expected that other common law provinces will enact similar provisions in the future (Craig Brown, "Alberta broadens scope of its Insurance Act,” The Lawyers Weekly 28:33 (16 January 2009)). See Insurance Regulation, BC Reg 213/2011, s 13(4)(c). 
was noted that this provision is part of the "consumer protection measures ... which will increase the protection for a non-culpable person or parties who may otherwise be denied insurance coverage because of the wrongdoing of another." 9 The section is "there to protect the interests of a party to an insurance policy who is non-culpable in terms of an offence or an action." ${ }^{10}$ It will ensure that an innocent co-insured will still be entitled to coverage under the insurance policy even where the criminal act of a co-insured was the cause of the loss: "The section provides that, if a contract excludes losses caused by the wrongful acts of an insured person, the exclusion applies only to defeat the claims of that wrongdoer, and cannot be used against an 'innocent co-insured', who will still be able to recover for losses proportionate to their share of the property."

Although the impetus for the provision relating to recovery by innocent co-insureds was principally to protect persons in abusive relationships, ${ }^{12}$ application of the provision is not limited to the domestic setting. However, section 35(1)(d) provides for the enactment of regulations to specify a class of persons prescribed and therefore excluded from the protection accorded the innocent co-insured, even if they are unconnected to the intentional or criminal conduct. Currently, legal entities or artificial persons, that is persons other than natural persons, are prescribed and therefore not entitled to indemnification as innocent coinsureds. ${ }^{13}$

The provision relating to the innocent insured reverses the majority of the Supreme Court of Canada decision in Scott, where the claim of an innocent named insured was defeated because damage to the subject property resulted from their teenage son, who was an unnamed insured in the policy, deliberately setting fire to the house. ${ }^{14}$ The decision was based on the combination of an expansive definition of "insured" that included both the named insured and those under 21 years old in the insured's care, and a clause denying indemnification for damage caused by wilful or criminal acts of any insured.

\section{Why IS SUCH A PROVISION NECESSARY?}

The issue of the innocent co-insured often arises in the context of homeowner policies. These policies tend to provide coverage for a broad range of persons under the same insurance contract. Coverage extends beyond the named insureds to include unnamed insureds who are other people living at the property, either long- or short-term, and who may have distinct interests. The liberal construction of persons covered by a homeowner's policy is intended to protect consumers and promote efficiency; but it can have the opposite effect when criminal or intentional conduct exclusion clauses apply to the actions of both named and unnamed insureds and the wrongdoing of one insured bars other insureds from

British Columbia, Official Report of Debates of the Legislative Assembly (Hansard), 39th Parl, 1st Sess, Vol 4, No 2 (6 October 2009) at 984 (Hon C Hansen).

Ibid.

British Columbia, Ministry of Finance, Insurance Act Regulations Discussion Paper (February 2010) at 12, online: Ministry of Finance <http://www.fin.gov.bc.ca/prs/fcsp/insurance_regs_discussion_ paper.pdf>.

Ibid. The paper states that the "primary purpose of the new provision is the protection of individuals in abusive relationships.”

Insurance Regulation, supra note 8, s 7(1).

Scott, supra note 6 at $1445-46$. 
recovering for their own losses. This can create an unanticipated risk for the innocent insureds.

In Scott, the plaintiff's house was damaged in a fire that had been deliberately started by their son and which the parents had no knowledge of. The expansive definition of "insured" in the insurance contract included the named insured and those under 21 years old in the insured's care. The contract also contained a clause against indemnification for loss or damage caused by wilful or criminal acts of any insured. As such, the insurer denied coverage for loss arising from the son's deliberate conduct. The majority of the Supreme Court of Canada found the son to be an unnamed insured within the definition of "insured" contained in the policy, and that his interest was not limited to his personal possessions and was therefore not distinct from his parents' interests. Hence, the son's actions resulted in the failure of the entire policy. ${ }^{15}$ The liberal construction of persons covered by a homeowner's policy applied by the Court in Scott created a situation where the policyholder was not protected because the Court focused on the language of the contract without regard to the broader public policy concerns of protecting the interests of non-culpable persons and their reasonable expectations.

The dissent in Scott found that a reasonable person would not expect to lose their right to recover under an insurance policy where damage or loss did not result from their own actions. Furthermore, the dissent found that the son's interest was separate from the parents' interests and was limited to the value of his possessions. ${ }^{16}$ This position seeks to adopt the modern American practice of treating insureds' interests as severable and not joint.

The problem of the denial of coverage for an innocent co-insured also arises where a spouse or another person covered by the insurance contract as an "insured" deliberately damages insured property. It is not uncommon for the issue to arise in the context of domestic violence, separation, and/or divorce where one spouse or cohabitant sets the insured property on fire or otherwise causes damage or loss as means of terrorizing their victims, who are predominantly women and children. ${ }^{17}$

Ibid at $1467-68$.

Ibid at $1457,1462$.

In 2009, Canadian women were about three times as likely as men to be the victims of spousal homicide: Statistics Canada, Family Violence in Canada: A Statistical Profile, Catalogue No 85-224-x (Ottawa: Statistics Canada, 2011) at 6, online: Statistics Canada <http://www.statcan.gc.ca/pub/85-224x2010000-eng.pdf > . See also Gecho v BCAA Insurance Corp (1997), 43 CCLI (2d) 157 (BCCA), rev'g (1996), 35 CCLI (2d) 178 (BCSC) [Gecho]. In this case, the husband intentionally burned down the family home following an argument with his wife. At trial, the judge determined that the loss was covered by the policy; however, on appeal, it was found that the loss fell within exclusion clauses since he was a spouse residing in the house. The Court of Appeal held that the exclusion clause must either stand or fall together. A similar case is Walsh v Canadian General Insurance Co (1989), 60 DLR (4th) 358 (Nfld CA), rev'g (1988), 30 CCLI 242 (Nfld SC (TD)) [Walsh]. In Walsh, the husband intentionally burned down the matrimonial home, which was owned by the wife. As in Gecho, the spouse was found to be an insured covered by the insurance policy and the exclusion clause operated to exclude intentional or criminal acts of any insured resulting in coverage being denied. While the trial judge held the wife's claim was not barred by the acts of her husband, it was held on appeal that the husband's interest was the same as joint tenancy. They held that if the wife were to succeed, it would be to her half-interest only; however, this was not the case, as the policy was found to be joint. See also Poon v Gordon (2002), 36 CCLI (3d) 147 (Ont SCJ) [Poon]; Torchia v Royal \& SunAlliance Insurance Co of Canada (2004), 71 OR (3d) 511 (CA) [Torchia]. 
The principle of personal responsibility ensures that family members who are unconnected with the conduct that caused property damage or loss do not have to face criminal sanctions for the wrongdoer's conduct. This principle does not apply in the context of insurance and the it does not ensure the indemnification of the victims' losses where the perpetrator and victim are jointly insured under the same policy. This exacerbates survivors' vulnerabilities, as they may not recover insurance proceeds to rebuild their lives - even in situations where the perpetrator only had a beneficial interest in the property. This gives abusers an opportunity to further victimize their targets. This outcome is inconsistent with the reasonable expectations of the reasonable person; as the dissent discussed in Scott, a reasonable person would not expect their claim for indemnity to be defeated when they are unconnected with the conduct that caused the loss in question. ${ }^{18}$ Rather, the reasonable person would consider their interests and obligations relating to the subject property and the insurer's indemnification obligations as several and not joint with others insured by the same policy. ${ }^{19}$ This understanding of the rights and obligations under an insurance contract is consistent with the principle of personal responsibility by which persons unconnected with the wrongdoing in question should not have to pay for it unless there is a duty obliging them to do so; for example a duty based on the concept of vicarious liability. For the innocent coinsured, their loss is fortuitous and should otherwise be entitled to indemnification without triggering concerns about moral hazards, provided the wrongdoer does not benefit from indemnification of the innocent party. As well, barring the innocent co-insured from recovering for their loss does not further the public policy objectives underlying the criminal forfeiture principle. $^{20}$

In addition, the innocent co-insured could be subject to a subrogation claim where the insured property is subject to a mortgage and the policy in question includes a mortgage clause in favour of the mortgagee pursuant to a covenant to insure. This is possible because a mortgage clause creates two parallel contracts: one between the insurer and mortgagor, and another between the insurer and mortgagee. ${ }^{21}$ An insurer is not entitled to void the contract or relieve itself of its indemnification obligation to the mortgagee as a result of the mortgagor's intentional damage or loss to the subject property. Therefore, an innocent coinsured can be exposed to a subrogation claim when a policy pays a mortgagee where the language of the contract indicates that the rights and obligations of the insured are considered joint and not several. The common law principle that prevents an insurer from subrogating against its own insured is not offended because the mortgage clause creates a separate contract between the insurer and the mortgagee. The insured mortgagor is a stranger or third party to the contract between the insurer and the mortgagee. Hence, an insurer who indemnifies the mortgagee pursuant to the mortgage clause, or a contingent insurance contract regarding the mortgagee's interest in the subject property, is entitled to exercise a right of subrogation against the insured mortgagor to the extent of the amount paid to the mortgagee. ${ }^{22}$ Alternatively, the mortgagee may obtain its own insurance to protect its interest 
in the mortgaged property and the mortgagee’s insurer may make a subrogation claim against the innocent co-insured.

\section{CRIMinal Forfeiture Principle}

The common law criminal forfeiture principle is triggered where loss or damage is caused by the insured's deliberate or criminal conduct, arson for example. The criminal forfeiture principle bars indemnification under an otherwise valid insurance contract for reasons of public policy. The principle holds that it is contrary to societal values for persons to be indemnified for losses purposefully caused by them and thereby benefit from their own wrongdoing. The criminal forfeiture principle also precludes recovery by the wrongdoer's estate and anyone with a derivative claim through that estate. The rationale is that the estate and those claiming through it are in the same position as the criminal.

Unfortunately, the principle has some unintended consequences. In addition to barring the wrongdoer's claim, it precludes indemnification of third parties who suffer losses arising from the insured's deliberate conduct. In most cases, innocent victims remain uncompensated because wrongdoers are often unable to satisfy damages from their personal assets. Another victim of the criminal forfeiture principle could be innocent co-insureds who are considered joint with the insured whose wrongdoing caused the loss or damage.

Insurance statutes have modified the common law criminal forfeiture principle to provide for indemnification where loss results from unintended consequences of the insured's deliberate conduct. Thus, insurance coverage may be available where the insured's conduct is deliberate but the resulting loss or damage was unintended, unless the policy explicitly excludes coverage for loss or damage caused by intentional or criminal conduct. ${ }^{23}$ A duty to defend can therefore arise where youth have started a fire, for example as a prank, that has caused consequential property damage. ${ }^{24}$ The focus on unintended consequences is consistent with the underlying purpose of insurance as a mechanism for protection against fortuitous or unexpected losses. This protects insureds and innocent third parties who suffer losses from the unintended consequences of the insured's deliberate conduct.

The statutory amendments regarding the criminal forfeiture principle preserves insurers' freedom to explicitly include the criminal forfeiture principle as a contractual term that excludes damage or losses caused by criminal conduct from coverage. Insurance contracts, therefore, often specifically exclude coverage where loss or damage is caused by an insured's intentional or criminal conduct, or a person acting with the insured's consent. As noted by the Ontario Court of Appeal in Eichmanis v. Wawanesa Mutual Insurance Co. ${ }^{25}$ the statutory provision abrogating the common law criminal forfeiture principle is inapplicable where there is an explicit exclusion clause in the insurance contract. In this situation there is no 
requirement for the damage or loss to be intended and there will never be indemnification for loss or damage resulting from the insured's deliberate or criminal conduct. ${ }^{26}$

The legislative provision, however, does not protect innocent co-insureds who suffer loss or damage caused by the deliberate conduct of a joint insured, or someone acting with the consent of an insured. In such cases, the co-insured's claim is barred by the intentional or criminal conduct exclusion clause in the policy precluding indemnification for loss caused by an insured's deliberate conduct. ${ }^{27}$ Thus, the benefit of the statutory modification to the criminal forfeiture principle is primarily limited to where the damage or loss is caused by the intentional or criminal act of a third party and not a co-insured.

\section{CLAIMS BY INNOCENT CO-INSUREDS: THE CONTRACTUAL APPROACH (MODERN APPROACH)}

Courts seek to give effect to parties' intentions as reflected in the terms of each policy. In recent years court decisions regarding claims of innocent co-insureds tend to focus on whether the loss in question is covered or excluded by the terms of the policy based on contract principles. The "new rule" or "modern approach" is firmly based in contract law, specifically on an examination of the policy for the definition of "insured" and the scope of the exclusion clause in order to determine whether an innocent co-insured is entitled to indemnification in the circumstances regardless of the nature of the insureds' interest in the subject property. Pursuant to the principle of contra proferentem, ambiguities in the language of the policy are resolved in favour of the insured and courts apply a rebuttable presumption that the rights and obligations under an insurance contract are several. Therefore, where the language of the contract is silent or ambiguous on whether the rights and obligations thereunder are joint, the insurer's indemnification obligations are deemed several in relation to each insured and an insured's wrongdoing will not affect the right of a co-insured to recover for their losses. ${ }^{28}$ This allows for individual responsibility for wrongdoing subject to the terms of the contract. ${ }^{29}$ Thus, unless the language of the policy states otherwise, an

In Eichmanis, ibid, a 15 year old who was an unnamed insured in a homeowners policy pled guilty to criminal negligence causing bodily harm under the Criminal Code, RSC 1985, c C-46, s 221. The homeowners' policy contained an intentional or criminal conduct exclusion. The Ontario Court of Appeal ruled that the criminal exclusion clause applied whether or not it was an intentional criminal act because if it applied only to intentional criminal acts the intentional conduct exclusion would be superfluous. Therefore, a criminal conduct exclusion clause would apply to any violation contained in the Criminal Code.

$27 \quad$ See Scott, supra note 6; Beck Estate v Johnston, Meirer Insurance Agencies Ltd, 2011 BCCA 250, 1 CCLI (5th) 167.

$28 \quad$ See Snaak (Litigation Guradian of) v Dominion of Canada General Insurance Co (2002), 61 OR (3d) 230 (CA); Higgins, supra note 20 at 372; Hedtcke v Sentry Insurance Co, 109 Wis 2d 461 (SC Wis 1982); W-V (T) vW (KRJ) (1996), 29 OR (3d) 277 at 285, 291 (distinguishes between "the" insured and "an" insured for exclusion clauses and found in favour of the innocent co-insured because the exclusion clause stated "the insured" but the act was done by another insured); Wawanesa Mutual Insurance Co v Hewson, 2003 SKQB 116, 231 Sask R 83; Wigmore v Canadian Surety Co (1996), 139 DLR (4th) 164 at paras 58-60 (Sask CA) [Wigmore (CA)].

29 The presumption of individual rights and obligations under the insurance contract has also been applied in relation to post-loss statutory obligations where the statutory condition in question does not unambiguously indicate joint responsibility. In Wigmore v Canadian Surety Co (1994), 124 Sask R 113 (QB) [Wigmore $(Q B)$ ], the Court held that breach of the statutory condition requiring an insured not to wilfully make false statements in the proof of loss vitiated the claim of the insured who filed the proof of loss but had no bearing on the claim of the spouse co-insured who was not part of the false statements. The Court adopted the presumption of individual responsibility, noting that had the legislature intended responsibility for wrongdoing to be joint, it would have used clear language to that effect (ibid at para 22). In addition, the policy was not sufficiently clear that responsibility for wrongdoing was joint as 
insured's wrongdoing is not imputed to the innocent co-insured. This protects the innocent co-insured from being "punished” for the wrongdoing of another insured.

The liberal construction of the policy terms in a manner favourable to the insured is consistent with the principle of broad interpretation of coverage provisions and narrow construction of exclusion clauses. Insurers have responded to what appears to be a position that favours the insured by drafting policies in a way that leaves no doubt that an insurer's indemnification obligations are joint and not several and that the misconduct of one insured precludes others whose interests are insured under the same contract from seeking indemnification for their own losses. ${ }^{30}$

Homeowners' policies broadly define "insured" to include not only the named insured but also any member of their household and persons under the age of 21 under their care, for example foster children and students in homestay programs. In addition, policies explicitly exclude the insurer's indemnification obligations for loss or damage caused by the criminal or intentional conduct of the named insured and any person whose property is insured. In Scott, the Court did not use the terminologies of the old and modern approaches, but the majority of the Court was clear it was simply giving effect to the intentions of the parties as reflected in the language of the policy. Justice L'Heureux-Dubè stated that "the terms of the insurance policy are perfectly clear and unambiguous. The policy does not cover the type of risk which occasioned this loss. Such risk was specifically excluded. The wording of the exclusion clause for the purposes of the present case is unambiguous, as is the definition of 'Insured." "31 She subsequently reiterated that the decision was based on contract law principles when she stated:

\footnotetext{
Were I convinced that a different interpretation would advance the true intent of the parties, I would gladly subscribe to it. However, when the wording of a contract is unambiguous, as in my view it is in this case, courts should not give it a meaning different from that which is expressed by its clear terms, unless the contract is unreasonable or has an effect contrary to the intention of the parties. In the present case, the policy of insurance excludes liability of the insurer for damage caused by the criminal or wilful acts of the insured. The definition of "Insured" clearly includes the minor children living in the home ... I do not see how they could word their policy to exclude such a risk other than by the precise terms used in this policy. ${ }^{32}$
}

Emphasis on contractual interpretation in the application of the modern rule can create a formalistic approach that reflects property law principles and concepts of property ownership

$30 \quad$ opposed to several (ibid).

Some courts specifically advised insurers to insulate themselves from indemnification obligations to innocent co-insured by carefully drafting their policies to ensure that objective. In American Economy Insurance Co v Liggett, 426 NE 2d 136 at 141 (Ind App 1981) [Liggett], the Court not only told insurers to draft their policies to avoid several indemnification obligations but also suggested wording that could be used to achieve that goal:

[T]here is no reason why this implied exception cannot be made an express exception in the policy.

It could be written in bold letters and red ink across the face of the policy:

IF YOU OR ANY PERSON INSURED BY THIS POLICY DELIBERATELY CAUSES A LOSS TO PROPERTY INSURED THEN THIS POLICY IS VOID AND WE WILL NOT

REIMBURSE YOU OR ANYONE ELSE FOR THAT LOSS.

Scott, supra note 6 at 1465.

Ibid at 1467-68. See also Poon, supra note 17 at para 10; Torchia, supra note 17. 
rather than the purpose of insurance or the reasonable expectations of the insured. ${ }^{33}$ This can result in a situation contrary to the principle of personal responsibility, and contrary to the public policy rationale for the criminal forfeiture principle where innocent co-insureds are barred from recovery. ${ }^{34}$ Further, the underlying rationale of severability that is inherent in the modern approach is undermined and the public policy interests of protecting innocent parties is subordinated to the principle of contractual freedom. It leaves no room to protect the interests of unsuspecting insureds where the language of the contract unambiguously adopts joint responsibility for wrongdoing, and hence the insurer's indemnification obligations result in harsh outcomes for innocent co-insureds even under the modern approach.

\section{Vi. Conflating Property and Contract Principles AND UNDERMining PERSONAL RESPONSIBILITy}

There is no doubt that liability for the wrongdoing that causes damage to the insured property is several and does not extend to those unconnected with the wrongful conduct. The exclusion of the claims of innocent co-insureds presupposes joint interest or benefit in the insured property, joint contractual rights and obligations under the insurance contract, and an assumption of joint responsibility for the loss or damage. The assumption of joint responsibility is contrary to the centrality of the individual legal subject in Western liberal thought:

Western civilization is based upon the premise of individual responsibility for wrongdoing. We do not impose vicarious liability for torts (including fraud) on our spouses just because of the marital relationship. More appropriately... we do not impose vicarious liability for criminal conduct upon those who are totally innocent whether they are married to the criminal or not. ${ }^{35}$

Legal liability (whether criminal or civil) for the wrongdoing that caused property damage or loss is determined solely based on principles of individual autonomy and personal responsibility; individuals unconnected with the misconduct cannot be held liable regardless of their relationship with the wrongdoer. Barring claims of an innocent insured is an unreasonable interference with their autonomy interests that cannot be justified as a matter of social responsibility or necessary for the actualization of their autonomous self. ${ }^{36}$

Property law does not place an equivalent emphasis on the individual. Rather, property law incorporates notions of kinship and interdependency. Conceptualizing persons insured under an insurance contract as having a unified interest in insured property is rooted in notions of joint ownership or benefits from insured property - at least in relation to persons who jointly hold property. Joint interest or benefit is also assumed in relation to members of the same household based on the premise that they all stand to benefit from continued existence of the subject property and are likely to benefit from insurance proceeds for loss or damage to the property. This assumption is premised not only on concepts of property

\footnotetext{
33 See Erik Knutsen, “The innocent co-insured: Severable coverage could protect family members,” The Lawyers Weekly 31:6 (10 June 2011) 9.

See e.g. Scott, supra note 6.

Liggett, supra note 30 at 140.

This is likely a situation in which feminists would welcome separation of kin and independence as
} necessary for promoting one's interest and well-being. 
ownership but also reflects the social and cultural reality of interconnectedness and relational modes of human existence with its attendant values of reciprocal care and compassion. Some people may view the relational basis for the expansive definition of "insured" in homeowner policies as a justification and perhaps a common sense expectation of a shared sense of responsibility when loss or damage is caused by one insured.

The inconsistency between principles of personal responsibility for one's conduct and property law principles is revealed by situations involving innocent co-insureds. For example, in Scott the majority of the Court adopted a contractual approach to determine whether the innocent co-insured could recover for losses caused by the deliberate conduct of an insured that turned on the interpretation of the terms of the insurance contract, specifically the meaning of "insured" and the exclusion clause for loss caused by criminal or wilful conduct of an insured. ${ }^{37}$ The majority considered the nature of the co-insureds' interest in the insured property to be inseparably connected because each insured stood to gain in the continued existence of the property and would suffer prejudice from its destruction. ${ }^{38}$ Despite the fact that the insurance contract did not specifically state that the rights and obligations of those insured under the contract were joint, the Court determined that there were joint rights and obligations based on the alleged unitary nature of their interest in the insured property. This thereby created joint obligations under the insurance contract and consequently the wrongdoing of one insured tainted the entire policy and barred the other insureds from claiming indemnity for their own losses. This decision shows the strong influence of property law regarding the interpretation of insurance contracts.

The influence of property law principles and notions of kinship and interdependency in interpreting the terms of the insurance contract also runs counter to the principle that coverage provisions should be broadly interpreted and exclusion provisions narrowly construed when interpreting insurance contracts. Furthermore, insurance contracts should be interpreted to be consistent with the reasonable expectations and intentions of the parties in entering into the contract. ${ }^{39}$ As Justice La Forest (dissenting) noted in Scott:

[R] easonable persons, unversed in the niceties of insurance law, would, in purchasing fire insurance, expect that a policy naming them as an insured without qualification would insure them to the extent of their interest. Moreover, reasonable persons would expect that they would lose the right to recover for their own willful destruction. But the same persons would find it an anomalous result if informed that they stood to lose all if their spouse burned down their house. The following responses would be forthcoming: "I had nothing to do with that act of arson so why am I being punished for it? My 50 per cent interest in the house belongs to me. I could have taken out my own insurance policy on my interest; in that case if my spouse burnt down the house I was protected. Why should my getting paid depend on whether there is one policy or two? If it had been made clear to me, why would I have ever agreed to take out a ‘joint' policy? I only stood to lose.”40

37 Scott, supra note 6 at 1465-68.

$38 \quad$ Ibid at 1467. The Court relied on the expanded meaning of insurable interest adopted in Kosmopoulos $v$ Constitution Insurance Co, [1987] 1 SCR 2.

$39 \quad$ Gordon Hilliker, Liability Insurance Law in Canada, 5th ed (Markham: LexisNexis, 2011) at 39-40; Consolidated-Bathurst Export Ltd v Mutual Boiler and Machinery Insurance Co, [1980] 1 SCR 888; Non-Marine Underwriters, Lloyd's of London v Scalera, 2000 SCC 24, [2000] 1 SCR 551; Canadian National Railway Co $v$ Royal and Sun Alliance Insurance Co of Canada, 2008 SCC 66, [2008] 3 SCR 453 at paras 73-76. 
As Justice La Forest points out, one solution would be for every person with an interest in the subject property to separately insure their interest even if their interest in the property is joint. While this would ensure indemnification of innocent persons, it is inefficient and likely not how the average person considers protecting their interest in joint property.

The Court justified the majority Scott decision partly based on public policy grounds. The view was that recovery by the innocent co-insured undermined the public policy against a person benefitting from her or his own wrongdoing, whether directly or indirectly. The public policy concern was that recovery would normally be used to rebuild the damaged property, usually the family home, or could otherwise be used in ways that would benefit the person who caused the loss as a member of the innocent co-insured's family or household. In such cases, not only would the co-insureds be jointly insured, but more importantly their interests in the damaged property would be joint and hence considered "inseparably connected so that a loss or gain necessarily affects them both." ${ }^{41}$ In Scott, the insureds were perceived as having joint and non-severable interests not because the son jointly held property with his parents (the son only had a beneficial interest in property), but because of the nature of their relationship and the likelihood that he would benefit if his parents received an insurance payment. This is seen to be a sufficient reason to bar the claim of the innocent co-insured on grounds of public policy. ${ }^{42}$

It is likely that a spouse responsible for the loss or damage would share in the innocent coinsured's recovery for their proportionate interest. However, this should not preclude recovery by the innocent co-insured for their separate interest in the subject property. ${ }^{43}$ The legal basis for non-severable property interests originally arose as a way to protect married couples. As the Court points out in Liggett, it is unfortunate that non-severability is now used to deny recovery for an innocent insured in ways that exacerbate women's subordination and vulnerabilities. ${ }^{44}$ The origin of non-severable property interests appears to stem from the now statutorily abolished legal fiction of coverture that stated that married couples constitute a single legal entity and that the wife's identity and legal status was subordinate to her spouse and she was incapable of separately owning property. ${ }^{45}$ It appears that the rule barring an innocent co-insured from recovering where loss or damage was caused by an insured was strictly enforced in relation to married couples, especially where they jointly owned the subject property. ${ }^{46}$ The determination of an individual's legal rights and obligations based on an outdated and unjustifiable legal fiction that reflects patriarchal assumptions about married women does not reflect current social realities. It undermines legal reforms on women's equality and should not be endorsed by courts determining that property interests are non-severable. ${ }^{47}$ The public policy in favour of protecting the innocent co-insured's reasonable expectations of having their interest protected should trump the possibility of the

P Samuel \& Co v Dumas, [1924] AC 431 at 445 (HL), Viscount Cave [Dumas].

See also Walsh, supra note 17.

See Wigmore (QB), supra note 29 at para 60.

Supra note 30 at 140 .

See ibid at 139; Lori Chambers, Married Women and Property Law in Victorian Ontario (Toronto: University of Toronto Press, 1997) at 14.

See Liggett, ibid at 138.

See Susan Ingram \& Kris Inwood, "Property Ownership by Married Women in Victorian Ontario" (2000) 23:2 Dal LJ 406; Richard H Chused, “Married Women’s Property Law: 1800-1850” (1983) 71:5 Geo LJ 1359; Chambers, supra note 45. 
perpetrator sharing in the insurance proceeds. Nonetheless, the insurance money is the property of the innocent co-insured, and they are entitled to use it as they see fit.

Some courts have had no difficulty in allowing indemnification of innocent insureds where persons insured under a single policy have separate interests, distinct legal identities, or no personal or familial relationship between the culpable and non-culpable persons. The rationale is that without a personal relationship there would be no possibility of the wrongdoer benefiting from the co-insured's recovery, for example in a situation involving a mortgagor and a mortgagee as was in Dumas, or with regards to a business relationship with no family connection as was the situation in Higgins. ${ }^{48}$ It is important to recognize that the public policy against a person benefitting from their own wrongdoing is not a sufficient reason for barring the non-culpable insured's claim as there is an equally compelling public policy rationale supporting recovery by the innocent co-insured consistent with their reasonable expectation under insurance contracts. ${ }^{49}$ Courts are able to ascertain the extent of an innocent co-insured's interest in the subject property, and this is routinely done in many contexts, including separation and divorce.

\section{Statutory PRotection OF INNOCENT Co-INSUREDS}

The vulnerability of an innocent co-insured to the denial of coverage by an insurer is the mischief that section 35 of the new BC Insurance Act is intended to remedy. ${ }^{50}$ The provision protects innocent co-insureds whose claims may otherwise be denied where the loss was caused by the intentional or criminal conduct of a co-insured under the same policy and the claimant is unconnected with the conduct in question. The provision is limited to protection of innocent co-insureds who are natural persons. ${ }^{51}$ Recovery by the innocent insured is not dependent on the nature of their interests in the subject property or terms of the contract. Rather, the provision abrogates insurers' contractual freedom to exclude coverage for loss intentionally caused by an insured vis-á-vis the innocent co-insured. The provision restricts application of the intentional or criminal conduct exclusion to those implicated in the wrongdoing or prescribed by regulation. It imposes several contractual obligations between the insurer and insured and allows indemnification where an insured is unconnected with the wrongful conduct of another insured that caused the loss. Thus, the provision upholds the principle of personal responsibility because non-culpable co-insureds cannot be "punished" or denied indemnification for their loss where damage or loss has been caused by the intentional or criminal act of a co-insured, and it simultaneously ensures that persons who are implicated in the wrongdoing in question are denied recovery for their loss under the insurance contract. The provision maintains an insurer's right to exclude losses deliberately caused by the conduct of an insured person under section 5, but ensures that the application

48 See also Inland Kenworth Ltd v Insurance Corp of British Columbia (1990), 66 DLR (4th) 374 (BCSC). In Liggett, supra note 30 at 148-49, the Court clearly stated that the decision may serve as a precedent for insurance cases involving legal relationships other than married couples such as persons in business relationships, for example partners, corporate officers, mortgagees, landlord-tenant, and joint ventures. In McKay v Cowan (1995), 123 DLR (4th) 336 at paras 65-67 (BCCA), the liability policy in question covered a firm of lawyers against acts, omissions, or personal injuries resulting from their practice. The policy contained an express provision of severability of the insureds. Thus, the intentional wrongdoing of one partner in defrauding his clients did not affect coverage for the innocent insureds.

Wigmore (CA), supra note 28 at para 40.

Supra note 3, s 35. See also Alberta Insurance Act, supra note 3, s 541.

BC Insurance Act, ibid, s 35(1)(d); Insurance Regulation, supra note 8, s 7(1). 
of the exclusion clause is limited to the culpable person. This is also consistent with the reasonable expectations of average insureds and the overall consumer protection focus of the new insurance legislation. ${ }^{52}$ The provision gives the innocent insured the same rights of indemnification as if the damage or loss in question has been brought about by the conduct of a third party not insured by the policy in question. Consistent with the public policy against wrongdoers obtaining indemnification for their losses, recovery is limited to the proportionate share of the innocent co-insured's interest in the insured property. ${ }^{53}$ The provision also avoids reliance on property law concepts of ownership in the subject property and relational concepts to determine or animate rights and obligations under the policy. However, the nature of the non-culpable insured's relationship with the subject property may be relevant in determining the extent of their interest and hence recovery under the policy.

There is a quid pro quo expected of the innocent co-insured whose claim would otherwise have been denied in an effort to avoid fraud. The innocent co-insured is required to assist in the investigation and cooperate with the insurer in investigating the loss, including "submitting to an examination under oath, if requested by the insurer, and ... producing for examination at a reasonable time and place designated by the insurer, documents specified by the insurer that relate to the loss."54

The provision adopts the modern approach of severability of insureds - the minority view in Scott. A non-culpable insured's right of recovery is no longer dependent on the language of the insurance contract to determine whether the contract adopts joint or several responsibility for wrongdoing. This is consistent with the pro-consumer focus of the amendments. The provision resolves the inconsistent case law by replacing decisions based on the construction of the terms of the insurance contract with clearer statutory provisions. More importantly, the provision protects the interests of survivors of domestic violence (who are mostly women and children) when abusive partners, believing that the abused spouse will be prevented from recovering under the insurance policy, cause damage or loss to the insured property, usually the family home. It also protects parents who suffer losses at the hands of their children. The purpose of insurance as providing indemnification for uncertain losses is preserved, as the losses remain fortuitous for the innocent co-insured.

\section{CONCLUSION}

While section 35 of the BC Insurance Act seeks to protect the interest of innocent coinsureds, one of the difficulties that may arise is how to determine the person's proportionate interest in the subject property. Scott indicates that homeowners will be able to recover the entire value of the property where the culpable insured had only a beneficial interest, as in the case of a child or other members of the household. There could be particular concerns, for example in cases of a spouse who intentionally burns down the family home where that home is jointly held, about how to determine the innocent insured's proportionate interest in a property. There could be precedent from other areas of law where the nature and extent of a person's interest in property is routinely determined, such as family law and debtor-creditor

See the dissent in Scott, supra note 6 at 1453.

BC Insurance Act, supra note 3, s 35(2).

Insurance Regulation, supra note 8, s 7(2). 
contexts. However, there is still the concern about potential social cost given the likelihood that these issues may be litigated.

As previously stated, one of the concerns around allowing an innocent co-insured to recover their interest in the property is that the culpable insured may benefit in turn from the recovery. There are also concerns about fraud by the non-culpable insured, collusion between insureds with the intent of collecting from a policy, and the vulnerability of insurers and other policyholders who contribute to the insurance pool with regards to claims that are not based on fortuitous losses. The provision seeks to address these concerns by limiting recovery to the proportionate share of the innocent co-insured's interest in the subject property. However, there is no guarantee the culpable person will not benefit from the proceeds where there is a continuing relationship with the co-insured.

The possibilities remain that the innocent co-insured will co-mingle insurance proceeds with assets shared with the wrongdoer where they are in a continuing relationship or that the wrongdoer can also benefit from the insurance proceeds through inheritance or as part of the innocent insured's estate based on their familial relationship. These possibilities may not be entirely preventable, as courts or insurers cannot control how an innocent co-insured will spend the insurance money. The fact that these possibilities exist does not undermine the legislation's support of the public policy that wrongdoers should not benefit from their own wrongdoing, nor does it justify eliminating the provision protecting the interest of the innocent co-insured - especially survivors of domestic violence. In any event, recovery will be limited to the innocent co-insured's proportionate share in the damaged or lost property.

As well, the provision is limited to property loss or damage suffered by the innocent coinsured. It does not protect innocent co-insureds and others who suffer bodily injury or death caused by intentional or criminal conduct where loss resulting from such conduct is excluded from the scope of coverage. The problem of precluding claims of innocent co-insureds often occurs in fire insurance cases where loss or damage is usually related to property. However, bodily injury or death could also result from the same wrongful conduct and should have been equally protected. In fact, homeowners' policies typically include coverage for the insured's personal liability for bodily injury and property damage unless the loss in question otherwise falls within the exclusion clause.

Further, an insurer can exercise its subrogation right against a co-insured who causes loss or damage on the ground that the exclusion clause operated to take them outside the scope of coverage, thereby allowing the insurer to maintain the subrogated claim against the wrongdoer. This may create a difficult situation where co-insureds are family members. 